\title{
分子結晶における電子ープロトン連動と機能性
}

Electron-proton Cooperation in Molecular Crystals

\author{
三谷洋興 北川宏 中筋一弘 * \\ Tadaoki MITANI Hiroshi KITAGAWA Kazuhiro NAKASUJI
}

\begin{abstract}
The cooperation of electron and proton in organic systems has a large potentiality for the creation of new molecular functions in molecular crystals. In this article, the electron-proton-cooperation in charge transfer crystals is reviewed, particularly focusing on the ir spectroscopy of the phase transition in quinhydrone charge-transfer crystals under high pressures. As an example of the electron-proton cooperation at ambient pressure, the metal-insulator phase transition observed in [Pd( $\mathrm{H}_{2-\mathrm{x}}$ EDAG) (HEDAG)]TCNQ (EDAG= ethylenediamino-glyoxime, $\mathrm{x}=\mathrm{ca} . \mathbf{0 . 7}$ ) is reported.

[charge transfer, proton transfer, electron-proton cooperation, $\mathrm{H}$-bond, phase transition, quinhydrone, [ $\left.P d\left(H_{2 \cdot x} E D A G\right)(H E D A G)\right] T C N Q$, ir spectroscopy, high pressure]
\end{abstract}

1. はじめに

分子間に形成された水素結合のプロトンの挙動 は、周りの分子の電荷分布に著しく依存することは よく知られた事実である[1]。特に、酵素などの生体 系においては、分子の酸化や還元反応に伴いさまざ まな興味あるプロトンの挙動が見られ、その運動は 生体機能に本質にかかわるものである。しかしなが ら、そこでの電子とプロトンの相互作用は余りに複 雑に絡み合っているために、まだ酵素の機能等をプ ロトンの運動から議論するまでに至っていない。そ こで、本研究では、周りの電子状態と水素結合との 関係を明確にして、電子ープロトン相互作用のもつ 意義を明らかにするために、水素結合を含む電荷移 動型錯体であるキンヒドロン結晶を取り上げた。ダ イヤモンドアンビルを用いてこの錯体に圧力を印加 することによって、分子間の電荷移動量を連続的に 制御し、分子間の電荷移動とプロトン移動に関する 情報を光学スペクトルから直接に得ることができ る。その結果、電子とプロトンの分子間移動はプロ トンの量子性に絡んだ一つの相転移現象として理解 できることが判明した。この連動現象の存在は、こ
れからの材料開発に新しい一つの指針を与えるだけ でなく、電子とプロトンの二つの電荷の自由度を もった素子機能の開発が可能であることを示唆する ものである。実際に、この連動現象の一つの応用と して、一次元電荷移動型金属錯体における絶縁体一 金属相転移が見出された。

この錯体では、分子間の水素結合が秩序状態にあ ると絶縁的な性質を示すが、水素結合が無秩序状態 になると、絶縁体一金属相転移が誘起され、電子も 分子間を自由に遍歷するようになる。本稿では、電 荷移動型錯体の特徴を簡単に紹介した後、水素結合 を含む電荷移動錯体の中で最も典型的なキンヒドロ ン化合物についての圧力下の赤外吸収スペクトル測 定結果を述べ[2]-[4]、次いで常圧において初めて観 測した連動現象の例として、上記の金属錯体におけ る水素結合格子の秩序一無秩序転移を詳しく紹介す る[5]-[7]。

\section{2. 電子とプロトンの連動[1]-[4]}

\section{1 電荷移動型錯体の特徵[4]}

電子供与体(ドナー分子;D)および電子受容体(アク

₹923-1292 石川県能美郡辰口町旭台 1-1 北陸先端科学技術大学院大学

Japan Advanced Institute of Science and Technology, Tatsunokuchi-cho, Ishikawa 923-1292

* $560-0043$ 豊中市待兼山町 $1-1$ 大阪大学理学研究科

Osaka University, Machikaneyama, Toyonaka, Osaka, 560-0043 


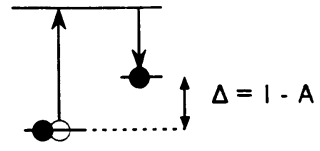

(D) (A)

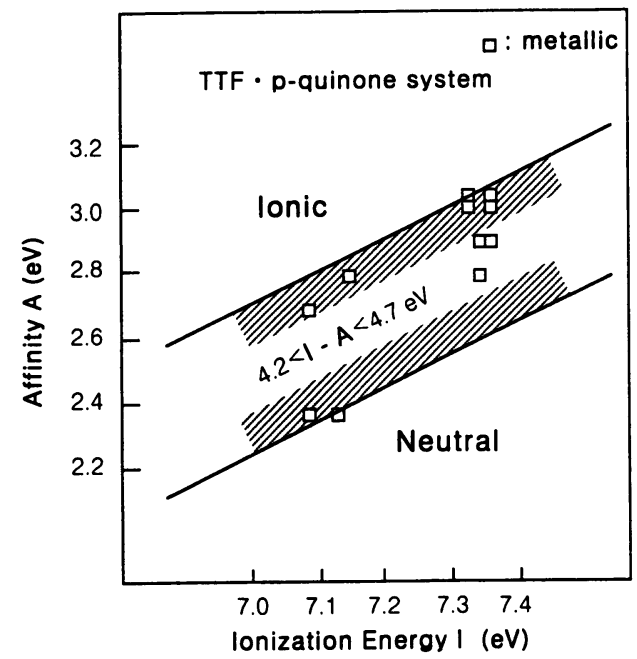

Fig. 1. Schematic diagram of the electrical properties of TTF-p-quinone system.

セプター分子:A)によって構成される電荷移動型錯体 は、結晶内でのD分子のイオン化エネルギー(I)とA分 子の電子親和力 $(\mathrm{A})$ が競合している点にその特色があ る。その差 $(\Delta=\mathrm{I}-\mathrm{A})$ が、DからAに電子が移動した ときに利得するペアー分子当たりの静電エネルギー より大きい場合には、錯体は中性の分子結晶を形成 するが、それより小さくなると、イオン性結晶が安 定化される。この境界領域では、D分子とA分子が 別々に配列した分離積層型の結晶構造が成長し、積 層間に中途半端な電荷移動が生じて金属的な性質が 現れる(Fig. 1参照)。一般的には、静電エネルギーの 利得が大きくなるように、D分子とA分子が交互に積 層する結晶系をつくる。境界領域に近い領域のいく つかの結晶では、温度降下や圧力印加によって格子 定数が小さくなり、静電エネルギーの利得が大きく なる結果、中性に近い状態からイオン性の状態へ転 移する現象(中性一イオン性相転移)が見いだされてい る[1]-[5]。この相転移近傍では、負性抵抗を伴った スイッチング現象[8]や巨大誘電応答[9]などが観測さ れており、結晶中の電荷分布は電場などの外部搨動 に対して敏感に応答することがわかる。

\section{2 水素結合型電荷移動錯体[3]}

$\mathrm{D}$ 分子としてハイドロキノン $(\mathrm{QH} 2) 、 \mathrm{~A}$ 分子として

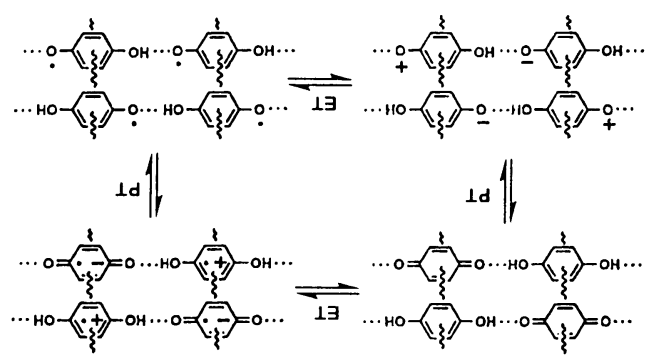

Fig. 2. Schematic molecular structures of the quinhydrone $(\mathrm{QH} 2, \mathrm{Q})$ complex under pressure.

ベンゾキノン $(\mathrm{Q})$ からなるキンヒドロン結晶は、入門 の教科書にも出てくる最も典型的な交互積層型の電 荷移動錯体である。常圧下では、層内のQH2 と $\mathrm{Q}$ 分子 間の $\pi$ 電子の重なりによって、QH2からQへの30\%前 後の電荷移動が生じている。これらのQH2とQ分子間 に水素結合が存在するが、その酸素原子間の距離は 標準的な值; $2.71 \AA ̊$ であり、常圧ではFig. 2の左上に示 した $(\mathrm{QH} 2, \mathrm{Q})$ 型の化学結合状態にある。

溶液中の電気化学反応のように、結晶中でも電子 移動やプロトン移動(それぞれ E T と P Tに対応)が起 こりうるとすると、イオン分子やセミキノンのみな らず、図の右下に示した中性ラジカルの分子結晶が 出現することも想定される。つまり、このような静 的もしくは動的な電子およびプロトン移動が起これ ば、四つの状態が混成し、この混成の仕方によって 各境界近傍で特徵的な物性の出現が期待される。前 述した中性ーイオン性相転移(不連続な上部のETに対 応した電子移動)をもつTTF・pークロラニル結晶で は、相転移近傍で中性領域とイオン性領域が共存す ることが確かめられている[8]、この共存が、ソリト ンやドメインによる新しい電導機構の形成や巨大誘 電応答の要因となっている[8],[9]。

\section{3. 圧カ下のキンヒドロン結晶[2]}

ダイヤモンド・アンビルセルを用いてキンヒドロ ン結晶に圧力を加えると、格子定数の減少に伴いイ オン化状態での静電エネルギーが大きくなり、イオ ン性相がより安定化される。同時に、電子の波動関 数の重なりとプロトンの量子的な運動、すなわちト ンネル運動の增加によって、Fig. 2に示したような状 態間の混成が生じる。この混成状態の情報を得る上 で光学的スペクトルは非常に有用であり、その測定 から圧力下での水素結合におけるプロトンのタイナ 


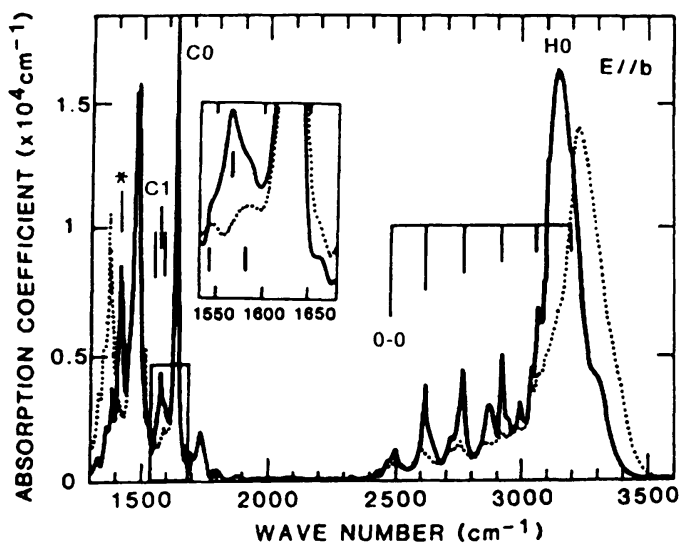

Fig. 3. Polarized ir absorption spectra of quinhydrone single crystal parallel to the $\mathrm{b}$ axis at $10 \mathrm{~K}$ (solid lines) and $300 \mathrm{~K}$ (broken lines. Inset: Magnified spectra in the region of the $\mathrm{C} 0$ and $\mathrm{Cl}$ bands.

ミックスに関する情報を得ることができる。例え ば、Fig. 2の右側の P Tによる相転移近傍では、ハイ ドロキノン型とセミキノン型の異なる水素結合の伸 縮振動モードが混在し、この二つのモードのエネル ギーシフトや振動子強度から分子間の電荷移動やプ ロトンのトンネル効果に関する知見を得ることがで きる。ここでは、プロトンのダイナミックスに直接 的に関与する $\mathrm{O}-\mathrm{H}$ 伸縮振動、分子の電荷分布の情報

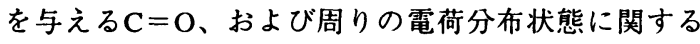

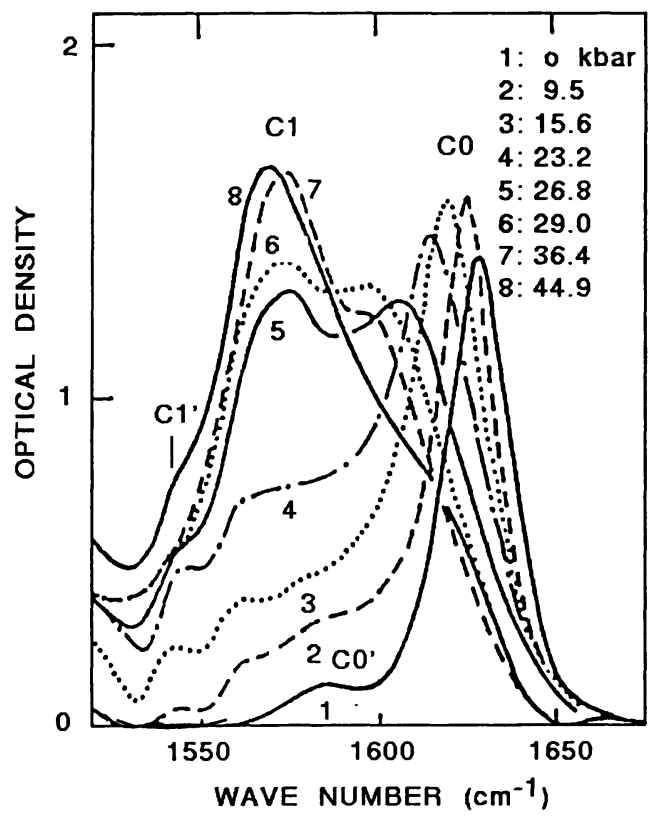

Fig. 4. Pressure dependence of the unpolarized absorption spectra of the $\mathrm{C}$ - $\mathrm{O}$ stretching mode in quinhydrone single crystal at $300 \mathrm{~K}$.
情報を与える分子間電荷移動(CT)遷移に関する光学 スペクトルについて述べることにする。

\section{1 赤外振動スペクトル}

Fig. 3には、キンヒドロン結晶の積層方向に垂直な 電気ベクトルをもつ光についての赤外振動スペクト ルを示した。 $3200 \mathrm{~cm}^{-1}$ 近傍には、OーH伸縮振動に対 応する幅広く強い吸収が見られる。低エネルギー側 $\left(1630 \mathrm{~cm}^{-1}\right)$ には、カルボニル基の $\mathrm{C}=0$ 伸縮振動によ る吸収 $(\mathrm{C} 0)$ が観測される。低温にすると、新しく $\mathrm{C} 1$ が現れるとともに、 $\mathrm{O}-\mathrm{H}$ 伸縮振動帯においても多数 の微細構造が現れる。これらの構造は、後述するよ うに、プロトンのトンネル効果によって $\mathrm{O}-\mathrm{H}$ 伸縮振 動がC一O伸䈹振動と結合したことによって生じたサ イドバンドであると解釈される。

\section{2 圧カ下での赤外振動スペクトル[4]}

常温のキンヒドロン単結晶に圧力を印加すると、 カルボニル基の伸縮振動による吸収スペクトルは、 Fig. 4に示したような変化を示す。低圧領域では、C0 吸収帯は圧力の増加とともに低エネルギーにシフト する。この $\mathrm{C}=\mathrm{O}$ 伸縮振動のシフトは、格子収縮に よってハイドロキノンとベンゾキノンの波動関数の 重なりが増し、ベンゾキノンへの平均の電荷移動量 が増加したことによると解釈される。

さらに圧力を加えると、低エネルギー側に新しい 吸収帯(C1)が現れ、25 kbar近傍では、C0とC1が共存 している。より高圧になると、C1が支配的になる。 この状態のままで低温にすると、COが消失し、低工 ネルギー側のC1'が強くなる(図示していない)。

Fig. 5には、圧力下のO-H伸縮振動スペクトルを 示した。 $\mathrm{C}=\mathrm{O}$ 伸縮振動の挙動と同様に、25 kbar近傍 で形状変化が著しく、そこでの共存状態を経た後、 高圧で別のスペクトル形状に転移する。この図で は、24 kbarまで印加した(共存状態)の後、そのまま $30 \mathrm{~K}$ まで冷却した場合の挙動が示されている。ただ し、この冷却操作は装置上の理由から圧力の上昇を 伴い、30 Kで約 $75 \mathrm{kbar}$ の高圧となっている。常圧に おける H0 が H1に転換し、より高圧(かつ低温)で は、二重構造 $\left.\left(\mathrm{H} 1 \text { と } \mathrm{H}^{\prime}\right)^{\prime}\right)$ が明暸に観測され、その間隔 は大きくなる。

このように、赤外スペクトルは、まず大きな不連 続な構造変化; $\mathrm{C} 0 \rightarrow \mathrm{C} 1$ および $\mathrm{H} 0 \rightarrow \mathrm{H} 1$ に特徴づけられ る。この変化は、Fig. 2の上部のET遷移に対応し、基 底状態が静電エネルギーの增加によって中性からイ オン性相に転移したと解釈される。この解釈は、転 移温度に至る圧力下 $(\mathrm{P} \mathrm{C})$ で、分子間の電荷移動(CT) 遷移の吸収端が急激に低エネルギーにシフトするこ 


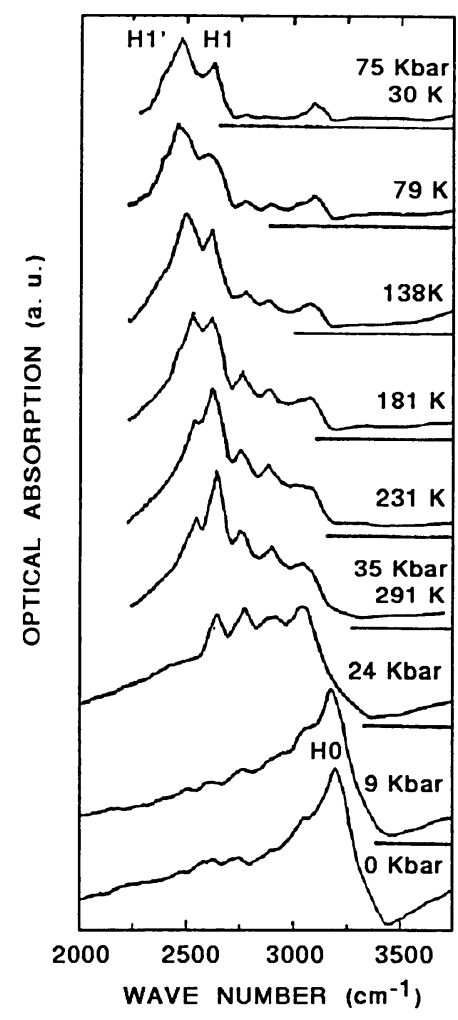

Fig. 5. Pressure dependence of the unpolarized absorption spectra of the $\mathrm{O}-\mathrm{H}$ stretching modes in quinhydrone single crystal at $291 \mathrm{~K}$ and its temperature dependence under high pressures (see text).

と[1]、あるいはCT遷移のない水素結合型結晶ではH0 $\rightarrow \mathrm{H} 1$ のスペクトル構造変化が観測されない実験事実 と符合する。P P c ( 25 kbar $)$ 近傍では、この二つ の基底状態が共存している。また、高圧低温領域で みられるH1とH1'はイオン相でのハイドロキノン $(\mathrm{QH})$ とセミキノン $(\mathrm{SQ})$ が同程度に存在していること を示唆している。

\section{3 圧カ下での○ーH伸縮振動の同位体効果[2],[4]}

上述したようなハイドロキノンとセミキノンの共 存が量子的な運動によるものか、あるいは熱的によ るものかを吟味することは非常に興味深い。そこ で、同一条件下での水素結合と重水素化された水素 結合の相違を明確にするために、約 $85 \%$ 重水素化し たキンヒドロン単結晶を用いて、OーHおよび $\mathrm{O}-\mathrm{D}$ 伸縮振動スペクトルの圧力依存性を測定した。その 結果をFig. 6に示した。

重水素原子の水素結合の場合は、イオン性領域の $\mathrm{O}-\mathrm{D}$ 伸縮振動スペクトル $\left(\sim 2000 \mathrm{~cm}^{-1}\right)$ に二重構造 (D1とD1’)が明瞭に観測されている。つまり、相転移

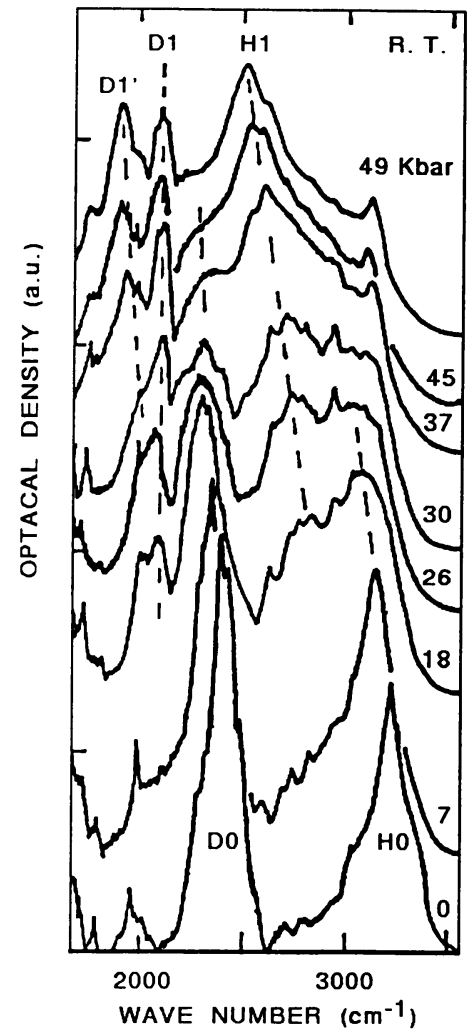

Fig. 6. Pressure dependence of the unpolarized absorption spectra of the $\mathrm{O}-\mathrm{H}$ and $\mathrm{O}-\mathrm{D}$ stretching modes in the $85 \%$ deutrated quinhydrone single crystal at $R$. T.

近傍においてもハイドロキノンとセミキノンの共存 が赤外スペクトルによって識別し得ることを示して いる。一方、 $\mathrm{O}-\mathrm{H}$ 伸縮振動では、分裂は識別できな い(一つのH1バンドとして観測され、高圧低温領域で は識別可能になる)。この違いは重水素と水素の量子 性の違いに起因させることができる。相転移近傍 で、プロトンはETの助けをかりて容易に分子間を移 動できるとすると、その移動頻度(エネルギー)が上記 の二重構造の分裂巾より大きい場合には、一つのバ ンドとして観測される。したがって、重水素化によ る分裂の観測は、プロトンの量子的運動の隇少とし て理解することができる。

このような電子移動の助けをかりた量子的なプロ トン運動は、水素結合型の電荷移動錯体における一 つの特徵として捉えることもできる。実際に、常圧 (中性相)のキンヒドロン結晶においても(Fig. 3参 照)、極低温にすると特徴のある微細構造(サイドバン ド)が現れ、その強度も温度降下にしたがって強くな り、その位置がイオン相に帰属されるH1のエネル 
ギー領域に観測されることは興味深い。その0-0遷 移の位置がH1’にほほ一致し、その間隔が $\mathrm{O} \cdots \mathrm{O}$ 対称 伸縮振動(約 $145 \mathrm{~cm}^{-1}$ )に対応していることから、この サイドバンドはトンネル効果を介した $\mathrm{C}-\mathrm{O}$ とOーH 伸縮振動の混合によるものと解釈できる。同様な意 味で、極低温のC一O伸䈹振動においても、C0のサイ ドバンドとしてC1が観測されているから、電荷移動 錯体におけるプロトンの量子性は中性相においても 無視できないものと考えられる。

\section{4. 電子ープロトン連動の応用[5]-[12]}

上述したように、キンヒドロンにおける水素結合 のプロトンは、分子間の電荷移動量が増すにつれて プロトン移動の確率が増し、中性ーイオン性相転移 近傍ではプロトンのトンネル効果が著しく大きくな ることが判明した。さらに、イオン相ではハイドロ キノンとセミキノンの共存が特徴的である。このよ うなイオン相での電子とプロトン移動の連動と量子 効果の増大を物性発現機構に応用した例を以下に述 ベる。

\section{1 水秦結合型分子性道体 [7]}

分子を用いて有機金属を合成するには、1.1章で述 ベたように、平面的なドナー(D)およびアクセプター (A)分子をそれぞれ分離して積層させて、その積層構 造間に中途半端な電荷の移動を生じさせることが最 も基本的な設計指針である。9)そこで、あらかじめ D 一 A 間に水素結合が形成されるような分子ペアーを 仕組んで、これを積層させると、Fig.7に示したよう な水素結合型一次元電荷移動錯体 ; $\left[\mathrm{Pd}\left(\mathrm{H}_{2-\mathrm{x}} \mathrm{EDAG}\right)\right.$ (HEDAG)] TCNQが出来上がる。ここで、 $\left(\mathrm{H}_{2} \mathrm{EDAG}\right)$ および(HEDAG) は dihydroーおよび hydroー ethylenediaminoglyoximeを表わす。ドナー分子であ る $\left[\mathrm{Pd}\left(\mathrm{H}_{2} \times \mathrm{EDAG}\right)(\mathrm{HEDAG})\right]$ とアクセプター分子であ るTCNQ(tetracyanoquinodimethane)がそれぞれab面

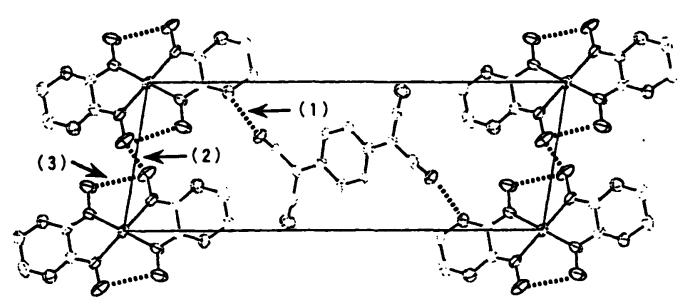

Fig. 7. The crystal structure of $\left[\mathrm{Pd}\left(\mathrm{H}_{2-\mathrm{x}} \mathrm{EDAG}\right)\right.$ (HEDAG)] TCNQ $(x=0.7)$ projected on the $a b$ plane.
に垂直方向に積層して結晶を構成している。Fig. 7で 示したこの結晶構造中には3種類の水素結合(図中の番 号に対応)が含まれ、それぞれに異なった役割をもっ ている：

(1)ドナーとアクセプター間の標準的な水素結合 $(\mathrm{N}$ $\mathrm{H} \cdots \mathrm{N}): 2.93 \AA(\mathrm{N}-\mathrm{N}$ 間の距離)

(2)ドナー分子間の強い水素結合 $(\mathrm{O}-\mathrm{H} \cdots \mathrm{O}): 2.59 \AA(\mathrm{O}$ 一O間の距離)

(3)ドナー分子内の共鳴構造をもつ水素結合 $(\mathrm{O}-\mathrm{H} \cdots$ O): $2.91 \AA(\mathrm{O}-\mathrm{O}$ 間の距離 $)$

ここで、(2)の水素結合は通常の水素結合と異なって いることに注意を要する。化学量論的な立場からこ の化合物の安定な分子構造を考えれば、[ $\mathrm{Pd}^{+2}$ $\left.\left(\mathrm{H}_{2} \mathrm{EDAG}\right)^{0}(\mathrm{HEDAG})^{-1}\right]^{+1} \mathrm{TCNQ}^{-1}$ のインン結晶となる が、結晶育成中において溶液中の $\mathrm{pH}$ 濃度を変えると 脱プロトンが生じて、結晶が不完全なイオン結晶； $\left[\mathrm{Pd}\left(\mathrm{H}_{2-x} \mathrm{EDAG}\right)(\mathrm{HEDAG})\right]^{+(1-x)} \mathrm{TCNQ}^{-(1-x)}(\mathrm{x}=0.3)$ が成 長する。これを理解するために、その溶液中での反 応を下に示す。

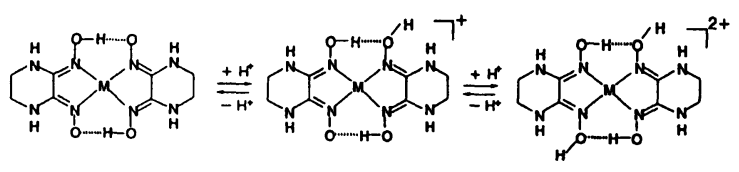

ここで脱プロトンされた中性の Pd(HEDAG) $(\text { HEDAG })^{\circ}$ (上部の左の分子)は結晶化される際に、 パートナーとして中性の $\mathrm{TCNQ}^{0}$ を選ぶことから、自 動的に結晶中で脱プロトンが起こると同時に、イオ ン性の $\mathrm{TCNQ}^{-1}$ 積層中に $\mathrm{TCNQ}^{0}$ が導入される[7]。赤 外吸収スペクトル、ラマン散乱あるいはX線解折によ る結合長解析7]によって、積層構造内で中途半端な電 荷状態 $(x \fallingdotseq 0.7)$ が生じていることが確認されている。 つまり、[Pd( $\left.\left.\mathrm{H}_{2-x} \mathrm{EDAG}\right)(\mathrm{HEDAG})\right]^{+(1-x)} \mathrm{TCNQ}^{-(1-x)}(\mathrm{x} \doteqdot$ 0.7)の化合物では、(2)の水素結合が30\%のプロトン の欠陥をもつとともに、TCNQの積層構造のバンドに $30 \%$ の正の電荷(ホール)を注入したことに相当する。 この錯体の電気伝導度を測定してみると、Fig. 8に示 したように、常温近傍では温度変化を全く示さない 金属的な振る舞いを示す。さらに低温では、180 Kに おいて、約 $50 \mathrm{~K}$ のヒステリシス幅をもった金属一絶 縁体相転移が観測される。TCNQの赤外 $\mathrm{C}-\mathrm{N}$ 伸維振

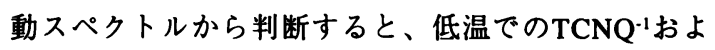
びTCNQ ${ }^{\circ}$ 対応した二重構造が見られ、180 K以上の 温度ではTCNQ-(1-x)に対応した一本の振動に転移する ことから、金属的挙動は、ホールが非局在化して $\mathrm{TCNQ}$ 積層上を遍歴していることによると理解されて 


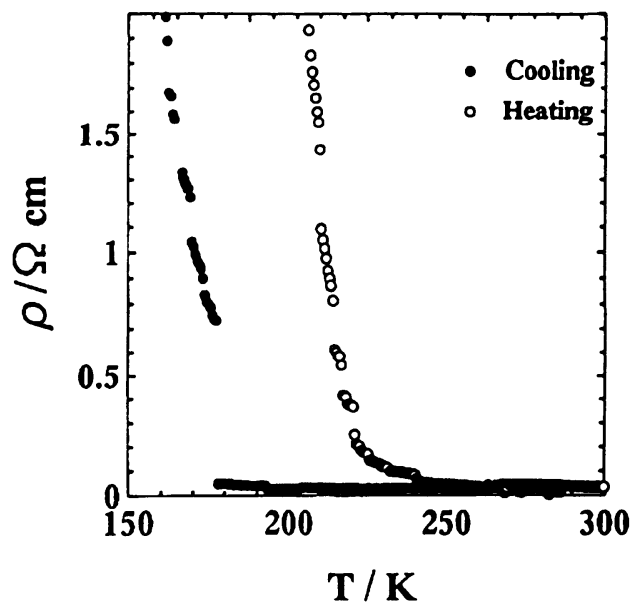

Fig. 8. Temperature dependence of resistivity of [Pd( $\left.\left.\mathrm{H}_{2-\mathrm{x}} \mathrm{EDAG}\right)(\mathrm{HEDAG})\right] \mathrm{TCNQ}(\mathrm{x}=0.7)$ single crystal.

いる。このような金属一絶縁体転移が前節に述べた ような電子ープロトン連動とどのような関連がある のか、つまり、脱プロトンした水素結合(2)における プロトンの運動と脱プロトンによって生じた金属的 ホールにどのような相関があるのか、これらの点に 注目して行った低温X線構造解析の結果を次章に述べ る。

\section{2 金属一絶緑体相転移 [7]}

金属一絶縁体相転移以下の温度での振動写真(液体 窒素温度)には、積層軸(c軸)方向に高い次数の周期 $\left(6 \mathrm{c} * / 12 、 4 \mathrm{c} * / 12 、 3 \mathrm{c} * / 12 、 \mathrm{c}^{*} / 12\right.$ など)をもった超格 子のスポットが現れる[7]。そこで、以下に記載する 自動追尾X線構造解析装置で測定した超格子の強度の 温度依存性を示したのがFig.9である。この挙動か ら、前述した $180 \mathrm{~K}$ 近傍の金属一絶縁体相転移がこの 超格子の出現と直接的な相関をもつと推論される。

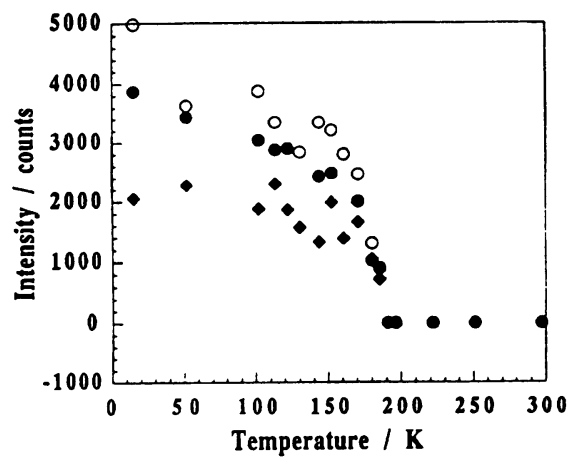

Fig. 9. Temperature dependence of $X$-ray reflection caused by superstructure of [ $\mathrm{Pd}\left(\mathrm{H}_{2-x} \mathrm{EDAG}\right)$ (HEDAG)]TCNQ $(x=0.7)$ single crystal. Spots $(O, O$ and $)$ are not assigned (see text).
残念ながら、観測された超格子が三次元的な秩序を もつものの、その次数が高いために超格子を含めた 全X線構造解析が出来るまでには至っていない。従っ て、Fig.9のスポット（○、○および○）の帰属はな されていない。そのために、超格子を除いて精密な 構造解析の温度依存性を調べ、そこで得られる構造 因子の挙動から超格子の出現にかかわる要因を導き 出す手法をとった。

$\left[\mathrm{Pd}\left(\mathrm{H}_{2-\mathrm{x}} \mathrm{EDAG}\right)(\mathrm{HEDAG})\right] \mathrm{TCNQ}$ 錯体のように、重 い原子と水素原子が共存する系において、X線構造解 折から温度依存性を含めた水素結合の挙動を明らか にすることは必ずしも容易なことではない。そのた めに、我々はイメーシングプレート方式を採用して バックグラウンドノイズを軽減するとともに、試料 を低温に冷却することによって生じる位置の変動を 補正できる自動追尾X線構造解析装置を開発した。こ れによってX線回折強度を一定に保つことができ、極 低温に至る温度領域まで、これまであまり議論の対 象にならなかった水素結合の温度因子についての議 論ができるデータが得られた。

\section{3 水素結合の融解 [7]}

$\left[\mathrm{Pd}\left(\mathrm{H}_{2-\mathrm{x}} \mathrm{EDAG}\right)(\mathrm{HEDAG})\right] \mathrm{TCNQ}$ 錯体では、分子の

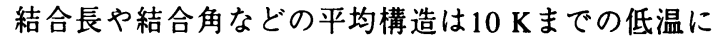
冷却しても僅かに減少するのみで昇温と降温過程に も有為な差は認められなかった。ただ、Fig.7中の(2)

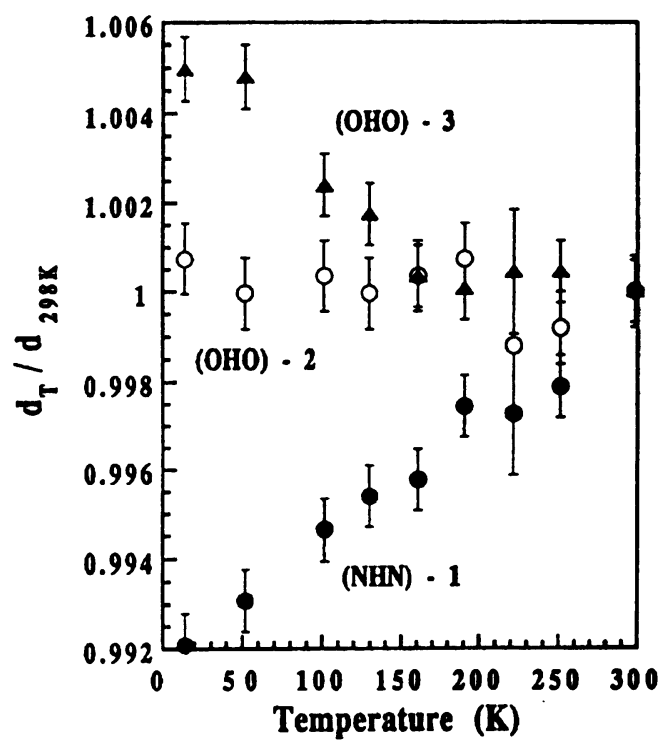

Fig. 10. Temperature dependence of hydrogen bond lengths normalized at $300 \mathrm{~K}$ for (1) $\mathrm{N}-\mathrm{N},(2) \mathrm{O}-\mathrm{O}$, and (3) $\mathrm{O}-\mathrm{O}$ (see Fig. 7). 
と(3)に関わる水素結合距離が低温になるに従ってむ しろ增加する特徴をもつことがわかった(Fig. 10参 照)。ここでの解析は、上述したように、超格子の存 在を無視した近似で行ったものであるが、この水素 結合の変化は超格子の出現と原因を同じくする可能 性が高い。実際に、すべての原子の温度因子の温度 依存性を調べてみると、(2)と(3)の水素結合に直接に 関与する酸素原子のみが超格子の出現とともに異常 を示すことが判明した。その様子を示すとFig. 11に なる。c軸方向には異常がなく、ab面においてのみ異 常が起こっている事実はFig. 10の結果とも一致して いる。温度因子が電子の時間的ゆらぎと空間的な乱 れの和であることを考えれば、直線的な減少は熟運 動によるものであり、低温部での温度因子の増加は 超格子の発生に伴う新たな空間的な電子雲の変調を 反映したものと考えられる。ここでの解析からは、 (2)のプロトンはOーO間のほほ中央付近に位置するこ とは主張できるが、脱プロトンによる影響もあり、O 一O間にプロトンの二つのサイトがあるかどうかにつ いては明確ではない。その内容を議論するには超格 子を含めたより箃密な全構造解析を待たねばならな いが、これに関して次のような興味深い赤外分光実

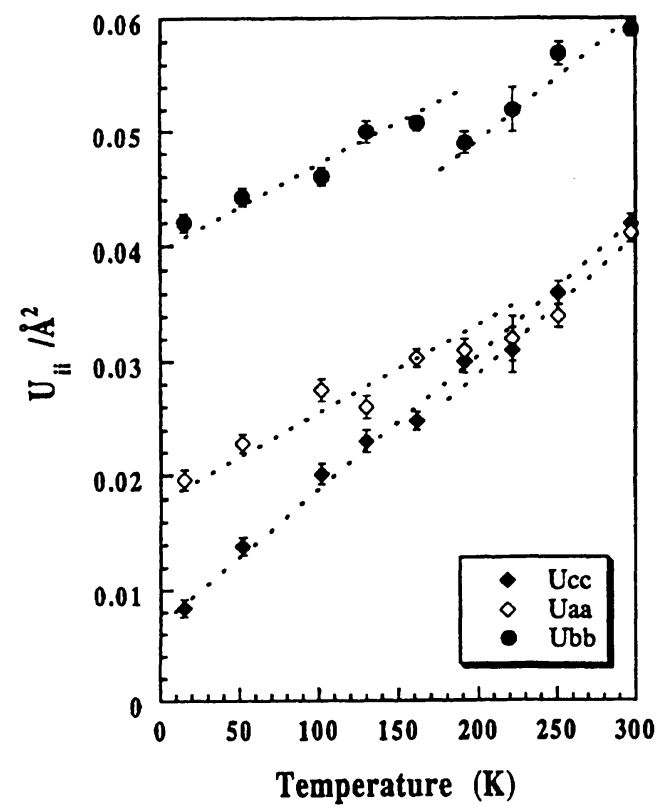

Fig. 11. Temperature dependence of anisotropic temperature factors for the $\mathrm{O}$ atom related with the hydrogen bond (2).

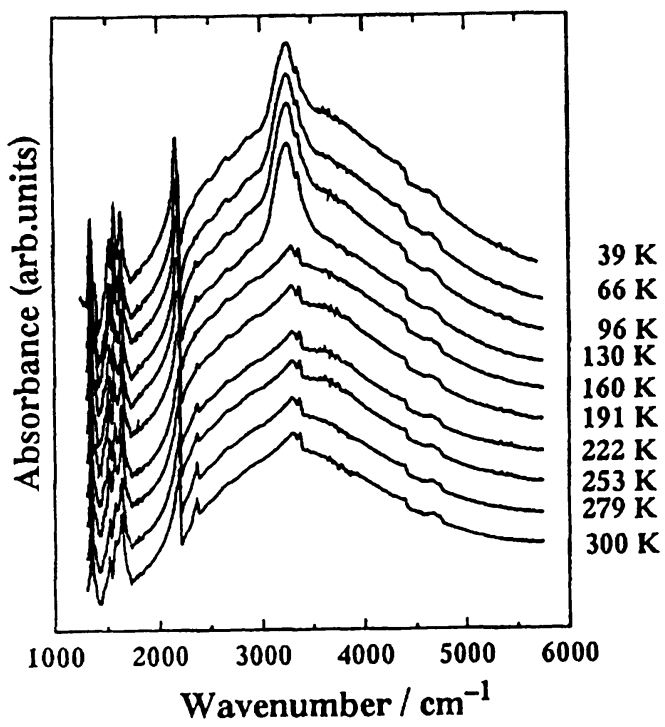

Fig. 12. Temperature dependence of the ir spectra of $\left[\mathrm{Pd}\left(\mathrm{H}_{2-\mathrm{x}} \mathrm{EDAG}\right)(\mathrm{HEDAG})\right] \mathrm{TCNQ}(\mathrm{x}=0.7)$ powder at ambient pressure.

験の結果がある。

Fig. 12に、赤外領域の吸収スペクトルの温度依存 性を示した。超格子が見られる低温の温度領域で $3200 \mathrm{~cm}^{-1}$ 近傍に巾の広い吸収帯が観測される。この 吸収帯は水素結合におけるプロトンの伸縮振動によ るものと考えられるが、そのエネルギー位置から判

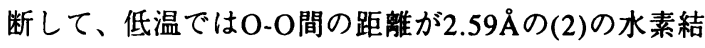
合によるものと考えられる。相転移以上の温度で超 格子の消滅に伴い水素結合の伸縮振動が観測されな くなることは、この水素結合のプロトンが、3次元的 な水素結合の秩序一無秩序転移に伴って、秩序状態 でのOーH振動状態から頻繁にプロトン移動が生じる 状態へ遷移したものと理解される。つまり、水素結 合の融解である。

以上総括すると、 $\left[\mathrm{Pd}\left(\mathrm{H}_{2-x} \mathrm{EDAG}\right)(\mathrm{HEDAG})\right] \mathrm{TCNQ}$ 錯体で観測された金属一絶縁体相転移は、D分子間 に存在する水素結合におけるプロトンの運動が、遠 くに離れた $\mathrm{A}$ 分子積層上の電子の運動と連動してい ることに起因する。このような一見不思議と思える ような現象の裏には、次のような化学のからくりが 隠れている。

ここでD分子として用いている $\left[\mathrm{Pd}\left(\mathrm{H}_{2 \cdot \mathrm{x}} \mathrm{EDAG}\right)\right.$ (HEDAG)]は、4.1節でのべたように、溶液中では $\mathrm{p} \mathrm{H}$ に応じて脱プロトンされ、その脱プロトン量に応じ て分子の価数が変化している。言い換えれば、Fig. 13に模式的に示したa軸方向の水素結合鎖の中では、 $\mathrm{c}$ 軸方向に積層しているA分子からの電荷補償があれ 


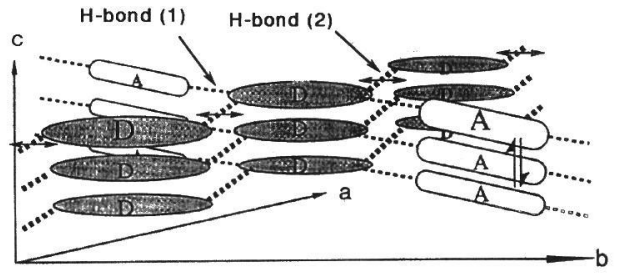

Fig. 13. Schematic H-bonded crystal structure of [Pd $\left(\mathrm{H}_{2-\mathrm{x}}\right.$ EDAG)(HEDAG)]TCNQ $(\mathrm{x}=0.7)$.

ば、溶液の中で起こるようなプロトン移動反応が金 属相で頻繁に起こっているを示している。つまり、 電荷移動相互作用を通じて、水素結合鎖のプロトン のゆらぎがTNCQ積層上の金属的なホールの運動と連 動している描像が浮かび上がる。

このプロトンの長距離秩序を伴った秩序一無秩序 相転移がプロトンの熱的あるいは量子的な運動によ るものかについての明確な答えはないが、水素結合 の融解によって金属状態が誘起されていることを考 慮すれば、おそらく量子的なものと考えてよいと思 われる。ここで述べた水素結合の融解と一次元分離 積層構造における金属一絶縁体転移の連動はこれま でにない現象であり、今後、基礎物性の新たな展開 のみならず、分子素子機能の開発を計る上で有用な 知見を与えるものであると考えられる。また、この ような連動現象が弱いシステムにおいては、一次元 の電子物性を緻密に制御する手段としても用いるこ とができるが、ここでは省略したので、文献を参照 されたい[10]-[12]。

\section{5.おわりに}

本稿では、圧力下で初めて明らかにされた電子と プロトンの連動現象が、水素結合に関連した物性開 発にどのように発展していったかを中心にして話を 進めてきた。圧力の印加によって生じる結晶中の捸 動は、電場や磁場によるそれに比べて極端に大き い。しかも、簡単に、連続的に、高い解析精度で、 極低温までの情報が得られる点で、物質探索のプ ローブとしての圧力実験は非常に価值の高いもので ある。特に、その結果を最近急速に進歩している合 成化学の技術と知識に結びつけることができれば、 さらに、その価值が増大することは間違いのないと ころである。このような意味で何かのきっかけを与 えることができればと思い、これまでの研究経過を
記した次第である。

\section{謝辞}

本稿で紹介した一連の研究は物理と化学の協力が あって初めて成し得たものであり、化学的な立場か ら協力していただいた斉藤軍治氏(京大理学部)に感謝 の意を表したい。

\section{参考文献}

[1]T. Mitani and T. Inabe: Advances in spectroscopy, VOL. 22, ed. by R. J. H. Clark andR. E. Hester,( John Wiley \& Sons, 1993) P. 291 "Spectroscopy of proton and electron cooperation system".

[2]T. Mitani, G. Saito, and H. Urayama:, Phys. Rev. Lett., 60, 2299 (1988), "Cooperative phenomena associated with electron and proton transfer in quinhydrone charge-transfer crystal".

[3] K. Nakasuji, T. Kitagawa, K. Okaniwa, T. Mitani: J. Am. Chem. Soc., 113, 1862-1864(1991), "Exploration of new cooperative proton-electron transfer (PET) systems. First example of extended conjugated quinhydrones:1,5-dihalo-2,6naphthoquinhydrones".

[4] 三谷洋興, 稲辺保, 岡本博: 応用物理, 58, 1014 (1989), ”有機結晶における電子およびプロトン移 動の制御”

[5]三谷洋興: 固体物理, 30, 147-156 (1995), ”電子プロトン結合系における新しい展開”。

[6] T. Mitani and H. Kitagawa: Electrical and Related Properties of Organic Solids, (Kluwer Academic, NATO ASI Series, Vol. 24, 1997) p. 12, "Electronproton cooperation in 1-D metallic states".

[7] 三谷洋興, 北川宏, 森井克行: 日本結晶学会誌、40, 83-89 (1998), ”水素結合と電子状態”。

[8] 十倉好紀:日本結晶学会誌, 30, 49-59 (1995)”有 機低次元半導体の光物性”.

[9] 菅原正, 待田智行:固体物理, 30, 137-146 (1995), ” プロトンダイナミックスを利用した低次元有機誘電 体の設計” .

[10]H. Okamoto T. Mitani, K. Toriumi, and M. Yamashita, "Photogeneration of solitons and polarons in 1-D halogen-bridged metal complexes" , Phys. Rev. Lett., 69 (1992) .

[11]岡本博, 三谷洋興: 固体物理 28, 407-421 (1993) " 擬一次元ハロゲン架橋金属錯体における電子状態の 制御と光物性ーソリトン、ポーラロンのダイナ ミックスー".

[12]H. Okamoto, M. Yamashita, T. Mitani, and Y. Oka: Phys. Rev. Lett., 80, 861 (1998), "Conversion of excitons to spin-soliton pairs in quasi-onedimensional halogen-bridged metal complexes".

[1999 年10月 27 日受理] 